\title{
A new species of Hercostomus Loew (Diptera: Dolichopodidae) from Voronezhskaya Oblast, Russia
}

\section{Новый вид Hercostomus Loew (Diptera: Dolichopodidae) из Воронежкской области, Россия}

\author{
M.A. Chursina \\ М.А. Чурсина
}

Voronezh State University, University Sq. 1, Voronezh 394036 Russia. E-mail: chursina.1988@list.ru.

Воронежский государственный университет, Университетская пл. 1, Воронеж 394036 Россия.

Key words: Dolichopodidae, Hercostomus, new species, morphology, Voronezhskaya Oblast, Russia.

Ключевые слова: Dolichopodidae, Hercostomus, новый вид, морфология, Воронежская область, Россия.

\begin{abstract}
A new Dolichopodidae (Diptera) species, Hercostomus nebulosus sp.n., from Voronezhskaya Oblast of Russia is described and illustrated. The new species is strongly differs from representatives of Hercostomus Loew, 1857 and Gymnopternus Loew, 1857; it can be easily differentiate by the yellow elongated cerci from $G$. assimilis Staeger, 1842, and by the morphology of hypopygium and wing shape from G. blankaartensis Pollet, 1991.
\end{abstract}

Резюме. Описан и проиллюстрирован новый вид из семейства Dolichopodidae (Diptera), Hercostomus nebulosus sp.n., из Воронежской области (Россия). Новый вид значительно отличался от других видов Hercostomus Loew, 1857 и Gymnopternus Loew, 1857. Он близок к G. assimilis Staeger, 1842, но отличается от него по удлинённым жёлтым церкам. Кроме того, он близок к G. blankaartensis Pollet, 1991, но отличается по морфологии гипопигия и форме крыла.

\section{Introduction}

Identification techniques of species of the subfamily Dolichopodinae (Diptera, Dolichopodidae) usually are based on classical morphological traits, such as colour of postocular setae and legs, legs chaetotaxy, shape and colour of antennal postpedicel, the position of veins $R_{4+5}$ and $M_{1+2}$ and cercus size and shape [Brooks, 2005]. Dolichopus Latreille, 1796, Hercostomus Loew, 1857 and Gymnopternus Loew, 1857 are the largest genera in the subfamily [Grichanov, Brooks, 2016] and have a wide geographical distribution. In this paper, a new species, Hercostomus nebulosus sp.n., from Voronezh Region (Russia) is described and illustrated.

\section{Materials and method}

The holotype and paratypes of the new species as well as other material examined are housed at the collection of Voronezh State University. Specimens were photographed by means of a Levenhuk C NG microscopic camera. Morphological terminology follow Grichanov and Brooks [2016].

\section{Results}

\section{Hercostomus nebulosus Chursina, sp.n.} Figs. 1-4.

Material. Russia: Voronezbskaya Oblast: Holotype: Voronezh, Botanical Garden of Voronezh state university, $51^{\circ} 40^{\prime} \mathrm{N}, 39^{\circ} 22^{\prime} \mathrm{E}$, bank of the pond, 6.VI.2017, M.A. Chursina $10^{7}$ (Voronezh State University, Hnebul 001). Paratypes: Voronezh, Botanical Garden of Voronezh state university, $51^{\circ} 40^{\prime} \mathrm{N}, 39^{\circ} 22^{\prime} \mathrm{E}$, bank of the pond, 6.VII.2017, M.A. Chursina $-140^{\top} \sigma^{\prime \prime}, 19$ (Voronezh State University, Hnebul 002 - Hnebul 016); vill. Mitrophanovka, 49 $58^{\prime} \mathrm{N}, 39^{\circ} 41^{\prime} \mathrm{E}$, 15.VI.2016, M.A. Chursina - 30 $0^{\top}$, 1 우 (Voronezh State University, Hnebul 017 - Hnebul 020); Voronezh, Botanical Garden of Voronezh state university, $51^{\circ} 40^{\prime} \mathrm{N}, 39^{\circ} 22^{\prime} \mathrm{E}$, 22.VI.2018, M.A. Chursina - 10 (Voronezh State University, Hnebul 021).

Diagnosis. Face white; antenna black; postoculars black; postpedicel subtriangular slightly longer than wide. Wing vein $\mathrm{R}_{4+5}$ and $\mathrm{M}_{1+2}$ convergent near wing apex; legs mainly yellow; hypopygium with elongated triangular cercus.

Description. Male imago (Fig. 1). Body length: 2.5$2.6 \mathrm{~mm}$, wing length: $2.4-2.5 \mathrm{~mm}$.

Head. Antenna entirely black; postpedicel subtriangular with obtuse apex, almost 1.3 times as long as wide (Fig. 2). Arista-like stylus weakly pubescent, about 2.8 times longer than postpedicel, located in the middle of its dorsal side. Frons green, with pollinose. Eyes haired; face white, ending above lower eye margin; ratio of height of face to width under antennae and width at clypeus 0.35/0.16/0.08. Clypeus silvery-white; proboscis dark, palpi brown. Postocular setae whole black.

Thorax (Fig. 1). Green with metallic tinge, without pollinosity; 5 pairs of dorsocentral setae, 10 pairs of short acrostichal. Pleura metallic green, with slightly grey pollinosity. Propleuron with 1 strong black seta below, without hairs above. Scutellum with white hairs above, with 2 strong lateral and 2 short medial setae.

Legs. Mainly yellow, mid and hind coxa, apex of hind tibia, fore and mid tibia from basitarsus and hind tarsus dark; hind femora with apical dark spot at dorsal side; all tarsi simple. 

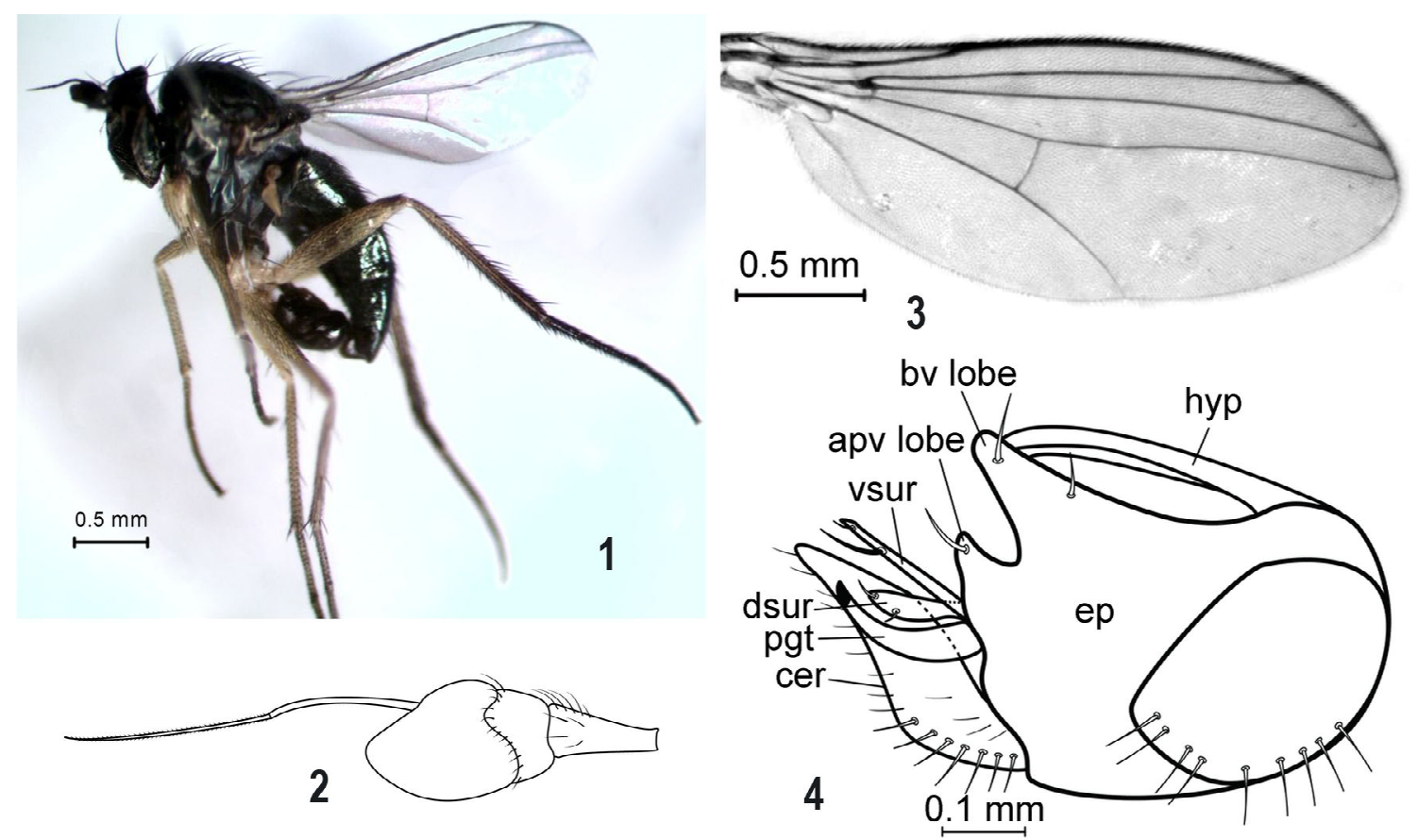

Figs 1-4. Imago male of Hercostomus nebulosus sp.n.: 1 - habitus, 2 - antennae, 3 - wing, 4 - hypopygium in lateral view (apv lobe - apicoventral epandrial lobe, bv lobe - basiventral epandrial lobe, cer - cerci, dsur - dorsal lobe of surstylus, ep - epandrium, hyp - hypandrium, pgt - postgonite, vsur - ventral lobe of surstylus).

Pис. 1-4. Имаго самџа Hercostomus nebulosus sp.n.: 1 - габитус, 2 - антенна, 3 - крыло, 4 - гипопигий, виА сбоку (apv lobe - апиковентральный эпандриальный вырост, bv lobe - базовентральный эпандриальный вырост, сег - церки, dsur - дорсальная сурстиль, ер - эпандрий, hyp - гипандрий, pgt - посттонит, vsur - вентральная сурстиль).

Hind femora with short ventral hairs. Fore coxae with black hairs and several strong setae apically, fore femora without subapical seta, fore tibia without long apicoventral seta, with row of small anteroventral setae at apical two-thirds. Ratio of length of fore tibia and tarsomere (from $1^{\text {st }}$ to $5^{\text {th }}$ ): 6.6/3.4/1.5/ 1.2/0.9/0.8. Mid coxae with several black setae apically; mid femora with 1 outer preapical seta; mid tibiae with 4 dorsal setae arranged in pairs at a distance of $1 / 4$ and $3 / 5$ from base; mid basitarsus without strong seta. Ratio of length of mid tibiae and tarsomeres (from $1^{\text {st }}$ to $5^{\text {th }}$ ): 9.25/4.1/2.6/2.1/1.5/ 0.85 . Hind coxae with 1 black seta; hind femur with 1 preapical seta; mid tibia with 3 anterodorsal, 2 dorsal, 1 posterodorsal and 2 apical anterodorsal setae distinctly longer than others. Hind basitarsus without strong setae. Ratio of length of mid tibia and tarsomere (from $1^{\text {st }}$ to $5^{\text {th }}$ ): $11.5 / 2.8 / 3.9 / 2.6 / 1.5 / 0.85$.

Wings (Fig. 3). Hyaline, veins brown; costal vein without thickening at tip of $\mathrm{R}_{I}$. Ratio of costal section between $\mathrm{R}_{2+3}$ and $\mathrm{R}_{4+5}$ to that between $\mathrm{R}_{4+5}$ and $\mathrm{M}_{1+2}-4.1 / 1.0$. Veins $\mathrm{R}_{4+5}^{2+3}$ and $\mathrm{M}_{l+2}^{4+5}$ slightly convergent apically. Ratio of basal section of $\mathrm{M}_{1+2}$ to apical one - 1.3/2.3. Apical part of $\mathrm{CuA}_{1}$ about 2.8 times longer than $\mathrm{m}-\mathrm{cu}$. Anal angle obtuse. Calypters yellow with black and several yellow cilia. Halter yellow.

Abdomen. Metallic green with blue tint, with black hairs and marginal setae; $6^{\text {th }}$ segment trapezoidal in lateral view; $7^{\text {th }}$ segment dark brown, forming well-developed peduncle. Male genitalia (Fig. 4): epandrium black, subrectangular in lateral view, about $1.6 \mathrm{x}$ as long as high; foramen positioned anterolaterally, well-separated from base of cerci, with pale setae; apical epandrial lobe well-developed, elongated-oval, with 1 strong light-colored lateral seta and 1 strong apical seta. Surstilus yellow, bilobed, both lobes long, thin; surstylus slightly shorter than cercus. Dorsal lobe thin, with strong black lateral seta, ventral lobe shorter than dorsal lobe, laterally flattened, with acute apex and 1 apical and 1 lateral setae. Cerci yellow, elongate-triangular, about 0.6 as long as epandrium, with long pale setae at base and several black apical setae.

Female. Similar to male.

\section{Addition to the key}

According to Stackelberg [1934], the new species is included in the third group of Hercostomus (femora yellow, postocular setae black). Similarity between the species and G. assimilis (Staeger, 1842) is based on the black antennae, the absence of a costal thickened at tip of $R_{1}$ and wing morphology (distal part of $M_{1+2}$ longer than basal part, $R_{4+5}$ and $M_{1+2}$ convergent apically), but H. nebulosus can be separated from it by the yellow elongated cercus (cercus dark brown and are not longer than its width in G. assimilis).

In the key of Negrobov and Stackelberg [Negrobov, Stackelberg, 1969] the new species runs to G. assimilis, and can be distinguished from the latter by the morphology of hypopygium and wing shape.

37. Cercus not longer than wide, dark brown G. assimilis (Staeger)

- Cercus almost 3.5 times as long as width, yellow H. nebulosus Chursina, sp.n. 
In the key to Palaearctic species [Selivanova et al., 2012], the new species runs to G. blankaartensis (Pollet, 1991), and can be distinguished from the latter by the morphology of hypopygium and wing shape.

27. Cerci quadrate, almost as long as wide; $R_{4+5}$ and $M_{1+2}$ parallel along whole length ... G. blankaartensis (Pollet)

- Cerci elongated triangular, almost 3.5 longer than width; $R_{4+5}$ and $M_{1+2}$ convergent apically

$$
\text { H. nebulosus Chursina, sp.n. }
$$

\section{Discussion}

H. nebulosus is close to the Hercostomus species. Although the morphological data revealed, that the new species runs to $G$. assimilis, $G$. blankaartensis and $H$. chetifer (Walker, 1849), but H. nebulosus can be distinguished from these species by the morphology of hypopygium, including cercus shape, wing shape and colour of lower postocular bristles. Comparing to $H$. chetifer (3.5 mm), H. nebulosus is a smaller species $(2.5 \mathrm{~mm})$. In addition, obvious diagnostic character of $H$. chetifer is modified $3^{\text {rd }}, 4^{\text {th }}$ and $5^{\text {th }}$ segments of fore tarsus: $3^{\text {rd }}$ and $4^{\text {th }}$ segments are black and flattened, and $5^{\text {th }}$ segment is white. Fore tarsi of $H$. nebulosus is simple.

\section{Acknowledgments}

The author is sincerely grateful to Dr. Oleg P. Negrobov (Voronezh, Russia) for his kindness in providing specimens for study.

\section{References}

Brooks S.E. 2005. Systematics and phylogeny of Dolichopodinae (Diptera: Dolichopodidae) // Zootaxa. No.857. P.1-158. doi: 10.5281/zenodo. 170753

Grichanov I.Ya., Brooks S.E., 2016. Dolichopodidae // KirkSpriggs A.H., Sinclair B.J. (Eds): Manual of Afrotropical Diptera. Vol.2. Sabni: Pretoria. P.485-540.

Negrobov O.P., Stackelberg A.A. 1969. Dolichopodidae // BeyBienko G.Ya. (Ed.): Keys to Insects of the European Part of the USSR. Vol.5. Part 1: Diptera, Siphonaptera. Leningrad: Nauka. P.670-750. [in Russian].

Selivanova O.O., Negrobov O.P., Nechay N.A., Maslova O.O. 2012. Key to the Palaearctic species of the genus Hercostomus Loew (Diptera, Dolichopodidae), Part 3 // Cesa News. Vol.78. P.1-6.

Stackelberg A.A. 1934. 29. Dolichopodidae // Die Fliegen der Palaearktischen Region. Vol.4. No.5. P.129-176. 